\title{
The Beach as a Tourist Commercial Use in Mexico. Comparative Study Mazatlán-Acapulco
}

\author{
La Playa como Uso Comercial Turístico en México. \\ Estudio Comparativo Mazatlán - Acapulco
A Praia como Uso Comercial Turístico no México. Estudo Comparativo Mazatlán-Acapulco

Ricardo Sonda de la Rosa.

Lic. Administración de Empresas Hoteleras, M.Sc. Turismo y Dirección Hotelera. Ph.D Administración. Universidad del Caribe, Cancún, Quintana Roo, México.

rsonda@ucaribe.edu.mx

(i) https://orcid.org/0000-0002-6788-4758

Damayanti Estolano Cristerna.

Ingeniera Industrial, M.Sc. Administración, Ph.D. Administración.

Universidad del Caribe, Cancún, Quintana Roo, México

sguerra@ucaribe.edu.mx

(D) https://orcid.org/0000-0002-4644-7102

Sandra Guerra Mondragón.

Lic. Turismo, M.Sc. Gestión Internacional de Negocios Turísticos, Ph.D(c) Investigación Turística. Universidad del Caribe, Cancún, Quintana Roo, México.

sguerra@ucaribe.edu.mx

(iD) https://orcid.org/0000-0002-2612-5034

\begin{abstract}
According to Richard Butler's theory on the life cycle of tourist destinations, the objective of the research is to make an inventory and compare the tourist businesses between two Mexican destinations. A mixed approach is applied through a case study methodological strategy, addressing qualitative aspects with phenomenological research. Commercial activities, that satisfy the requirements and expectations of tourists on the selected tourist beaches, were recorded, classified and compared. In the results section, the similarities and differences in the tourist businesses carried out are outlined, which will serve as input for future decision-making in matters of innovation and industrial strengthening of the products and services, offered and demanded.
\end{abstract}

Keywords: Tourism; Tourist industry; Beach. 


\section{RESUMEN}

Según la teoría de Richard Butler sobre el ciclo de vida de los destinos turísticos, el objetivo de la investigación es hacer un inventario y comparar los negocios turísticos entre dos destinos mexicanos. Se aplica un enfoque mixto a través de una estrategia metodológica de estudio de caso, abordando aspectos cualitativos con investigación fenomenológica. Se registraron, clasificaron y compararon actividades comerciales que satisfacen los requerimientos y expectativas de los turistas sobre las playas turísticas seleccionadas. En el apartado de resultados se esquematizan las similitudes y diferencias en los negocios turísticos realizados, lo que servirá de insumo para la toma de decisiones futuras en materia de innovación y fortalecimiento industrial de los productos y servicios, ofertados y demandados.

Palabras Clave: Turismo; Industria Turística; Playa.

\section{RESUMO}

Segundo a teoria de Richard Butler sobre o ciclo de vida de destinos turísticos, o objetivo da pesquisa é fazer um inventário e comparar os negócios turísticos entre dois destinos mexicanos. Uma abordagem mista é aplicada por meio de uma estratégia metodológica de estudo de caso, abordando aspectos qualitativos com pesquisa fenomenológica. As atividades comerciais que atendem às necessidades e expectativas dos turistas nas praias turísticas selecionadas foram registradas, classificadas e comparadas. Na secção de resultados, são delineadas as semelhanças e diferenças nos negócios turísticos realizados, que servirão de subsídio para futuras tomadas de decisão em matéria de inovação e fortalecimento industrial dos produtos e serviços oferecidos e procurados.

Palavras-chave: Turismo; Industria Turistica; Praia.

\section{INTRODUCTION}

Commercial activities are part of the tourist activity. These businesses in charge of providing goods and services to visitors are as impressive as necessary. Nowadays, these tourist businesses attend to the visitors' current requirements; however, the question is, are the tourist destinations prepared to receive the changes derived from an evolution according to the theory of the evolution of tourist destinations?

Analyzing the commercial, economic activity concerning the life cycle of touristic destinations proposed by Richard Butler (1980), which supports the definition of the most appropriate strategies to offer products or services for those who visit them, and by emphasizing the economic part of the businesses that are developed on the beaches of the touristic destinations, this article proposes to inventory, catalog and compare the commercial turns of two of the most classical Mexican destinations: the beaches of Mazatlán, Sinaloa, and the beaches of Acapulco, Guerrero.

The creation of new tourism products or services should not be considered lightly since knowing the past and visualizing the future will be a necessary activity to be relevant and efficient in tourism activity. There are few records of Mexican destinations' commercial activities at different stages, so this research acquires relevance when buying and analyzing commercial activities from a theoretical perspective, to innovate, consolidate, or even withdraw tourism businesses according to the contexts in which the evaluated destinations are found.

With the objective to inventory and compare, according to Richard Butler's theory of the life cycle of the tourist destinations, the tourist businesses between two destinations -Mazatlán and Acapulco-, using the mixed methodology applied on the case study, as referred by Creswell (2012), allows the analysis of specific contexts in specific times and places, using various sources of information in the collection of data to give a detailed description of a social phenomenon. Applying Butler's life cycle theory of tourism destinations, it will describe tourism business area and analyze their relevance in a national tourism context. Using this method was to have a descriptive ethnographic approach to identify and describe the variables that influence tourism destinations' life cycle. The study object's particularities were analyzed in two beach locations -Mazatlán and Acapulco- allowing a broader understanding of the tourism business phenomenon.

Comparing two tourist destinations requires an assessment of the circumstances of each context. Variables such as the type of tourists, the level of 
tourist expenditure, the perception of security or insecurity of the destination directly influence the touristic activity and determines factors in the choice of holiday sites (Sonda, 2014), as well as the complementary specific offer to each state framed in social, political and regulatory schemes which establish the strategies for marketing campaigns and holiday packages. As a result, the deliberate selection of studied destinations was mainly set with by the geographical location that allows, evaluating under the perspective of the life cycle of tourist destinations: Mazatlán (on consolidation) and Acapulco (on decline phase) to understand touristic business differences with a theoretical basis, different economic situations, with the same touristic purpose.

\section{The life cycle of touristic destinations}

Throughout history, proposals have been established to determine intermediate cycles in developing a tourist town, establishing stages in touristic destinations is not new. Gilbert (1939), Christaller (1964), Noronha (1976) and Miossec (1977) propose their contributions on the fact that touristic sites go through a series of phases or cycles throughout their life. However, the life cycle of a touristic destination, according to Butler (1980), is in itself one of the most relevant theories in the analysis of visitor profiles.

Butler's model has its origin in the product life cycle theory proposed by Dean (1950) in marketing, but it is adapted and related to the tourism industry's specific variables. Infrastructure, attitudes, the involvement of local agents, accessibility, competition, and, of course, marketing, with a series of characteristics described below, are considered:

Phase 1. Exploitation: The first phase occurs when countless individual tourists arrive at a given location, attracted chiefly by its natural or cultural assets. These are tourists who independently organize their trips and follow no tried-and-true recreation paths. Their impact on the lives of inhabitants and the local economy is minimal.

Phase 2. Involvement occurs when tourists visit an area in growing numbers, and some of the inhabitants begin to draw their livelihood from the accommodation, gastronomy, health services, and the like. The inhabitants' involvement proceeds by becoming active in the tourist economy or even focusing on visitors' activities. Expectations arise in the area for organized forms of recreation, and there is pressure to improve transport and conveniences for tourists.
Phase 3. Development: Phase begins now when the tourist area becomes one of the primary sources of income, and the number of tourists is either equivalent to or exceeds the number of permanent residents (at the same time, this is a signal that the tourist market is well defined in the area being studied). Tourist organizations from outside the tourist area enter the region, pushing out the local businesses and depriving the permanent residents of control over the development of how tourism functions in the area.

Phase 4. Consolidation: Phase marks the full development of tourism functions in a given area. It is characterized by reduced growth in tourists and tourism becoming the dominant industry in the local economy. A gap occurs between the spaces with the town's health/tourist functions (sanatoriums, hotels, restaurants) and social functions (e.g., households). Projects are taken up to extend the tourist season and expand the area in which services are offered. Antagonism from the local population can grow with the intensification of obstacles in running a business.

Phase 5. Stagnation: Phase brings a decisive halt to the growth dynamic of the number of visitors, the attainment of a maximum quantity of tourists in the area, and then a decline in the number of visitors. At this point, the area has a very well-defined profile, but it has ceased to be fashionable and its image no longer fits the region.

Phase 6. Rejuvenation or decline: Decline is characterized by a drop in tourists' numbers and the closure of unprofitable tourist sites or their transformation into typologically different venues (e.g., social care houses, private apartments). The area is no longer capable of rivaling other more attractive places for tourists. The services on offer are reduced, making the location increasingly unattractive, drawing less and fewer tourists. If the area has a sufficiently large infrastructure, weekend or one-day tourists appear. The local population becomes involved, this time generating demand by offering services that are accessible at a lower price. The decline phase can conclude within the total or partial disappearance of the tourist function in each area.

However, the area can enter a rejuvenation phase, though this is impossible without a conscious and involved program of activities to enhance the attributes that decide on an area's attractiveness. This can be achieved by introducing artificial attractions (e.g., turning buildings into a casino network) or using unexploited natural resources. 
Analyzing the model of touristic destinations can be used as an element in decision-making regarding marketing techniques to satisfy tourists' different needs and the stage conditions they are located. Mazatlán and Acapulco have characteristics of consolidation and stagnation, which need to be investigated to analyze the commercial developments in such representative touristic destinations.

The Secretary of Tourism of the Government of Mexico reported that the capture of foreign currency by international tourists in 2019 amounted to 15 thousand 666 million dollars, which represents an increase of 13.5 per year, compared to the same period 2018, arriving to count foreign travelers 29.8 million with a growth in the average expenditure of inbound tourists of 11.5 percent (Ministry of Tourism [SECTUR], 2020).

It is no coincidence that daily tourism is consolidated as an activity that, for many countries, is the engine of development, even considered as an emerging economy that provides well-being and social stability to countries, states or municipalities. Only in Mexico, at the end of 2019, comprehensively planned centers (Tourist centers developed from the beginning as a tourist destination away from the city where people who work for the hotel zone live), reported the end of 2019 in percentages of occupancy of the as follows: Los Cabos, California Sur, 71.3; Huatulco, in Oaxaca, 62.4; Ixtapa, in Guerrero, 58.8; and Cancun, in Quintana Roo, 72.2 (Ministry of Tourism [SECTUR], 2020). However, what about the classic destinations that were the forerunners of the tourism industry in the golden years?

\section{Mazatlán, Sinaloa}

Mazatlán is one of Mexico's most famous beach resort destinations, also known as the Pearl of the Pacific, and is home to resorts covering more than 17 kilometers of coastline. With more than 450,000 (INEGI 2010), Mazatlán's city has two main economic activities, fishing, and tourism. The first hotel in Mazatlán, which opened in 1850, was the Canton de la Fonda, owned by a Chinese immigrant; by 1864 and the end of the 19th century, new lodging establishments were built. It is more than 20 kilometers from the beach and is the main attraction with various hotels, restaurants, bars, and shops.

Mazatlán's boardwalk is considered one of the largest and longest in the world. In its almost 21 kilometers of coastline on the Pacific coast, there are developed commercial activities of all kinds, with panoramic roads, pedestrian walks, monuments, roundabouts, and various streets with history, art, and recreational spaces. Among the main attractions of the port are the Central Park 79 acres, currently being remodeled, the Mazatlán Lighthouse, the Mazatlán Aquarium -which houses various sections of marine fish, a botanical garden, sea lions, and an aviary.

One of the main annual festivities that Mazatlán boasts is its carnival, considered the most important in the Pacific, where more than 600,000 people gather. In its remodeled Teodoro Mariscal Stadium -the baseball season was noteworthy inaugurated almost 56 years ago-, the local Mazatlán Deer team of the Mexican Pacific League plays.

The main beaches in Mazatlán are Playa Norte, Playa Sábalo, Playa Cerritos, Playa Isla de la Piedra, Playa Isla de Venados, Playa Brujas, Playa Isla de Crestón, Playa Olas Altas, Playa La Marina and Playa Los Pinitos.

According to information from the Federal Secretary of Tourism (SECTUR), Sinaloa's state in 2019 had 14,982 rooms available. Mazatlán concentrated 9,975 , representing $66.58 \%$ of the state. And, in that same year, received the amount of $2,467,881$ tourists, which meant an increase of $14.54 \%$ over 2016; the overall percentage of hotel occupancy was located at $60.74 \%$ with an average stay of 2.8 days (Ayuntamiento de Mazatlán 2020).

\section{Acapulco, Guerrero}

Acapulco is in Guerrero's state on the Pacific coast of Mexico. Besides having been an essential seaport of commerce in New Spain, it is currently one of the most important touristic destinations in Mexico. Acapulco won worldwide fame in the 1950s with visits from Hollywood stars, and today it continues to be a favorite tourist destination for its beaches and nightlife that characterizes it. The city has just over 20 kilometers of beaches from Barra Vieja to the hill's foot, divided into three major tourist areas: Acapulco Traditional, Acapulco Dorado, and Acapulco Diamante.

Acapulco is the most populated city in Guerrero, with just over 673,479 inhabitants (INEGI 2019), plus those considered floating population that, according to the National Autonomous University of Mexico (UNAM), exceeds one million inhabitants. In terms of tourism, Acapulco is the city that pays more to the Municipal and State Council, with a state Gross Domestic Product (GDP) of 38.6 million pesos. The city's economy revolves mostly around the service sector, being a generator of jobs to operate its tourism activities. According to 
SECTUR, Acapulco recorded 5,225,259 tourists in 2019 and had an infrastructure of 18,972 hotel rooms in 2018, with an annual hotel occupancy rate of $46.6 \%$ (SECTUR, 2020).

Some of the main tourist attractions offered by the port of Acapulco are La Roqueta Island, La Quebrada, Diana Cazadora Fountain, Xtasea Tirolesa, El Malecón, Puerto Marqués, Pie de la Cuesta, Fórum Mundo Imperial, El Rollo Water Park, Sinfonía del Mar and Virgen de los Mares (Visitmexico, 2020).

One of the events that have positioned Acapulco as a world destination is the Tianguis Turístico, formerly called the International Fair of Hotels and Tourist Agencies of Acapulco, where the leading companies are dedicated to the industry meet to promote different tourist destinations in Mexico since 1975.

\section{The tourism business on the beaches}

Mazatlán and Acapulco's touristic destinations provide the economic indicators in the statistical tables generated where the tourist activity occurs, history of economic spillover, room-night occupation, average statistics, and several visitors in the destination. On a few occasions, these figures include those predetermined spaces that the present investigation proposes, the touristic destinations located in the "beach" category area.

One of the first studies concerning the typical conditions that develop on the beaches was done by Clark (1996), who propose five primary purposes: 1) Residential land use; 2 ) Use of fishing, oil, mineral or gas resources; 3 ) Construction of port facilities; 4) Conservation and protection of biodiversity, and 5) Tourism and recreational activities.

Continuing with the studies, Yepes (1999) postulated that the reasons why the beaches are the most representative and photographed spaces in the holidays by those who go there come from fully operational and administrative management of coordination of efforts in the municipal, state, federal, private or public initiative, where all of them give attractiveness to the touristic destinations. It is recommended that each tourism development has a clear and defined strategy on how it should manage its resources to effectively create competitive advantages, in harmony with balance and sustainability. Proper management of this resource will condition the tourism business's progress, quality, and permanence over time.
It is a reality that income that nourishes the industry is generated on the beaches of tourist destinations. Thanks to these economic activities, tourist growth is evident and complemented by several products and services such as cafeterias, restaurants, and massages, supermarkets, theme parks, tour sales, and more. In summary, the ordered management and the undoubted attraction of the 'beach' space, together with the undeniable desire to plan its use, have encouraged studying what happens in these spaces (Sonda, Escalona \& Morales, 2014).

One of the first studies on tourist beach behaviors was in 1995 when Valencia Tourism Institute shared that tourists spend between 3 to 5 hours a day on the beach; $78 \%$ of those tourists surveyed think that going to the beach is ideal. $73 \%$ think that relaxing and resting is just as crucial as sunbathing on the beach (Instituto Turístico de Valencia, 1995). This leaves no room for doubt about the beach's importance as a motivation.

Another study of beaches made by Marlowe (1999) carried out in the United States of America by the American Coastal Coalition in 1999, establishes that its coastal areas represent one-fifth of the territory of that country and that in 1997 it generated more than 185 billion dollars and created a little more than 2.7 million direct jobs. Visitors to Florida's beaches spend 11 billion dollars annually and 2 billion dollars only in the Miami area, a value that has increased to double in the last decade.

Considering the beach as a productive factor implies conceiving it as the result of the summarize of economic, social, and cultural efforts that take place on it, and in this way, understanding the development of the touristic businesses on the beaches of tourist destinations. For most people, the term 'beach' is used in a specific way in a tourism environment, and the picture of sand, sun, and sea immediately comes to mind. However, it should be known that we are talking about a set of attributes offered by a destination (Bejarano, 1997), which are built up thanks to the mass media, to a certain extent.

In order to inventory the touristic businesses on the beaches of the two previously mentioned destinations, it is necessary to define, in the first place, what the concepts of 'business', 'tourist business', and 'beach' mean for the research. Rondón (2010), in his work, defines "beach" as an accumulation of sediments deposited by waves and currents in coastal areas. We can speak of a theoretical profile of the beach in which we would have to differentiate between various morphological elements: 
Beachfront, an area that is always submerged, in which other minor topographic elements can be distinguished, forming bars and depressions.

Low beach, which remains submerged at each high tide, has a set of banks and depressions where the water remains during the ebb and flow and even at low tide.

High beach, an area where it is possible to distinguish between the berms, or small stepped projections, and the coastal range itself, which is higher.

The definition of a business is based on Diaz's (2003) book International Business, which refers it to the place where a job is done in order to receive a benefit, and this can be lucrative, with existing different ways of doing it because of the number of different similar activities between them.

For the definition of the tourism business, De la Torre (2003) considered it the occupation that an individual or company achieves, aiming to obtain an economic benefit with a turn that satisfies a tourist or visitor's need. The word business has its etymological meaning as 'without leisure,' referring to doing something for money (Verbiclara 2019). For this research, a touristic business is any activity that consists of receiving a dividend for the delivery of goods and services to improve income and reduce costs in order to become more efficient in the tourism industry.

\section{METHODOLOGY}

A methodology is an essential part of scientific research since a way of approaching a subject or object of study originated in a delimited problem. The approach used was of a mixed nature, using the quantitative part when carrying out the inventory type survey of each tourist business found, complemented by the qualitative part with the description of the activity in a socio-cultural environment. Using this type of methodology, the data obtained is the basis for reflection comparing and contrasting realities from an economic and social perspective (Szilasi, 2010).

This kind of research tries to address a place defined by the researcher in order to record phenomena of a social group from an aesthetic point of view through observation, with direct participation in each context, to analyze what is related to habits, customs, ways of being and behaviors, to interpret reality as a whole. Ethnography is a reflective practice since the counting, images, and visions elaborated concerning observation are directly related to the social phenomenon (Bryman, 2005).
The researcher means to approach the object of study for data recording constitutes the research instruments. There are four types: observation, textual analysis, interviews, and transcriptions; whether used individually or in combinations, they are both efficient and effective (Silverman, 2011).

In this sense, the observation was the primary research instrument, accumulating and interpreting the actions, behaviors, and facts of people or objects, as they usually do (Creswell, 2012), establishing the dependent variable touristic businesses, and the independent ones, beach, and location, as stated by Gundermann (2010), trying to give meaning according to other elements that can be explained in a given context.

It is essential to highlight that this research methodology was comparative, understanding how standard variables are diagnosed scientifically in different locations, to determine similarities, coincidences, or divergences that try to explain a present, past or future situation, and that through a systematic search, it is established whether the corresponding relationships or closeness exist towards a particular subject, like the case of the study is with two similar tourist destinations but with different origins.

Methodological strategy. This began with a physical and virtual bibliographic review of national and international websites, posts of scientific articles related to tourism and beaches, where useful results were found in order to make the decision and geographically delimit the field space to be investigated: Mazatlán and Acapulco, due to the economic spillover that they represent for their states, in addition to the number of workers in the industry and similar tourism offerings in both selected destinations.

At this time, the ethnographic work took on high relevance since the field survey was carried out physically on the beaches. The researcher carried a camera and a list, where he recorded the findings during the tours; the first one was in the beach area of Mazatlán with about $5 \mathrm{~km}$ from the Valentinos complex, covering the most representative beaches such as Playa del Cid and Los Sábalos. (Figure 1).

In Acapulco's case, the beaches' route was from the beginning of the Krystal Beach Acapulco Hotel to the Eighth Naval Region, with a little more than 6 km (Figure 2).

Once the tours were completed, secondary sources from various dictionaries and government websites were used, from Federal to State and Municipal in 
Mazatlán and Acapulco, to precisely understand companies' tours to the legislation of each state.

After the survey was filled, the data were categorized. The results were analyzed and interpreted according to the following categories: Hotels, Apartments, Restaurants, Street vendors, Umbrella rentals, Jet ski rentals, Parachute tours, Massages, Board rentals, Parking lots, Beach clubs,

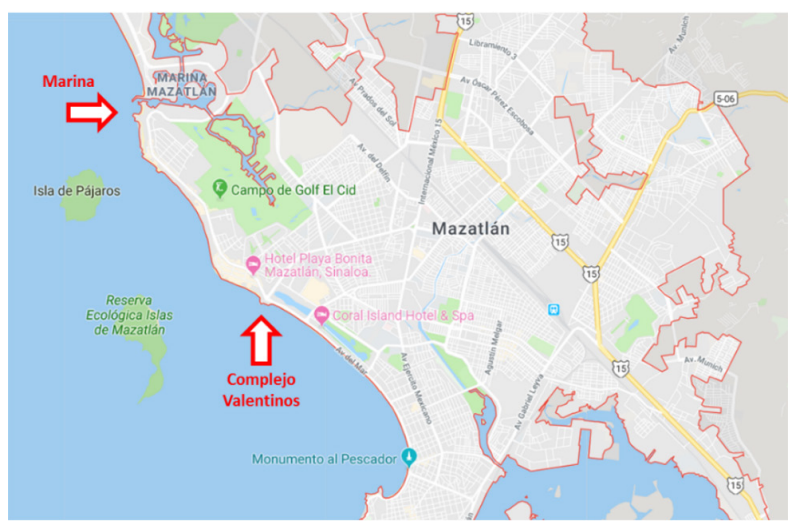

Figure 1. Delimitation of the study area Tourist Businesses in Mazatlán beach 2020.

Source: https://www.google.com.mx/maps/ place / Mazatl\%C3\%A1n, +Sin./ @23.238983, $106.4387639,13 \mathrm{z} / \mathrm{data}=! 4 \mathrm{~m} 5 ! 3 \mathrm{~m} 4$ ! $1 \mathrm{~s} 0 \times 869 \mathrm{f} 5341681837$ c1:0x62a4c4aaf13c72b2!8m2!3d23.2494148!4d-106.4111425

\section{RESULTS}

Mazatlán, Sinaloa is a classic and traditional tourist destination that since the beginning of touristic activity in Mexico presents the following number of tourist businesses, see Figure 3.
Supermarkets, Abandoned spaces, Diving tours, Private bathrooms, Bungee jumping, Water parks, Houses, Bungalows, Nightclubs, Cane rentals, Sailing boat rentals, Sports fields, Food kiosks. It is worth mentioning that these tourist destinations have a more significant offer of tourist services, but only those found in the beach area were registered and counted in a determined time.

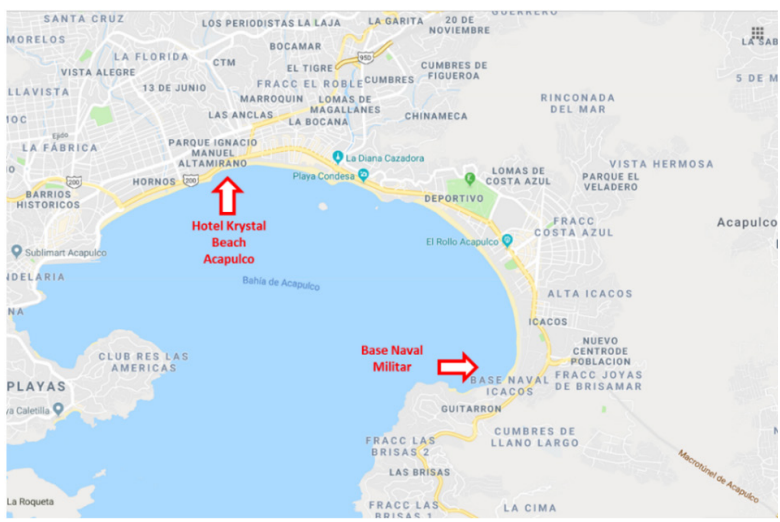

Figure 2. Delimitation of the study area Tourist Businesses in Acapulco beach 2020.

Source: https://www.google.com/maps/@16.846179,$99.8806089,14 z$

In the case of Acapulco, which has been operating as a tourist destination for more than 80 years, the following commercial activities are presented, see Figure 4.

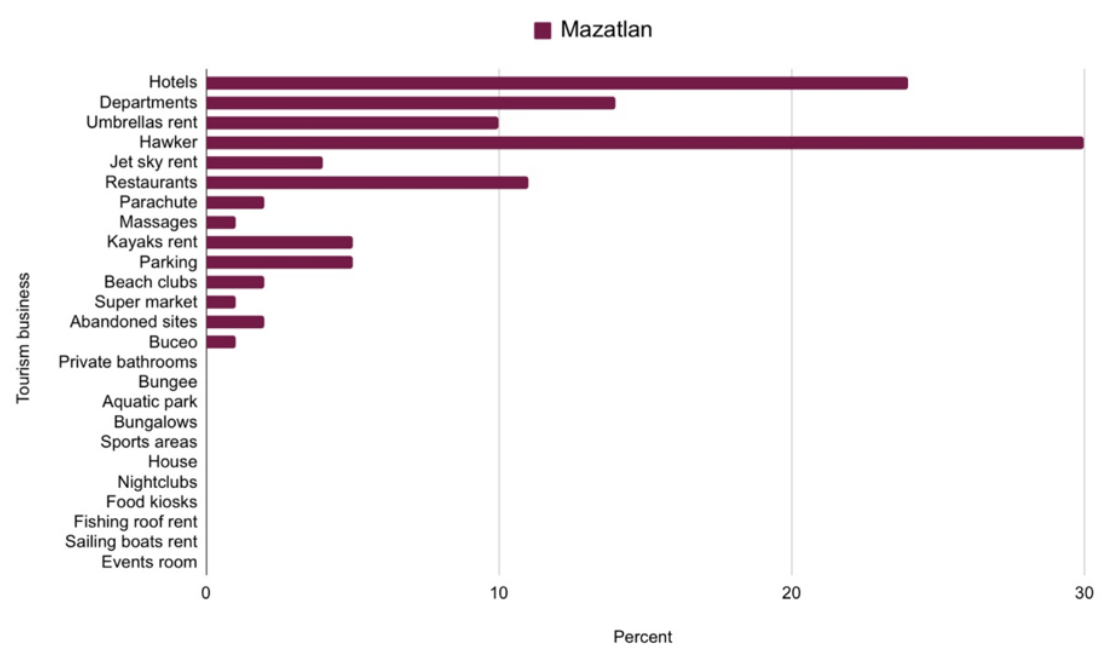

Figure 3. Results in percentages of the inventory of tourism businesses in Mazatlán's beaches in 2020. Source: Own elaboration. 


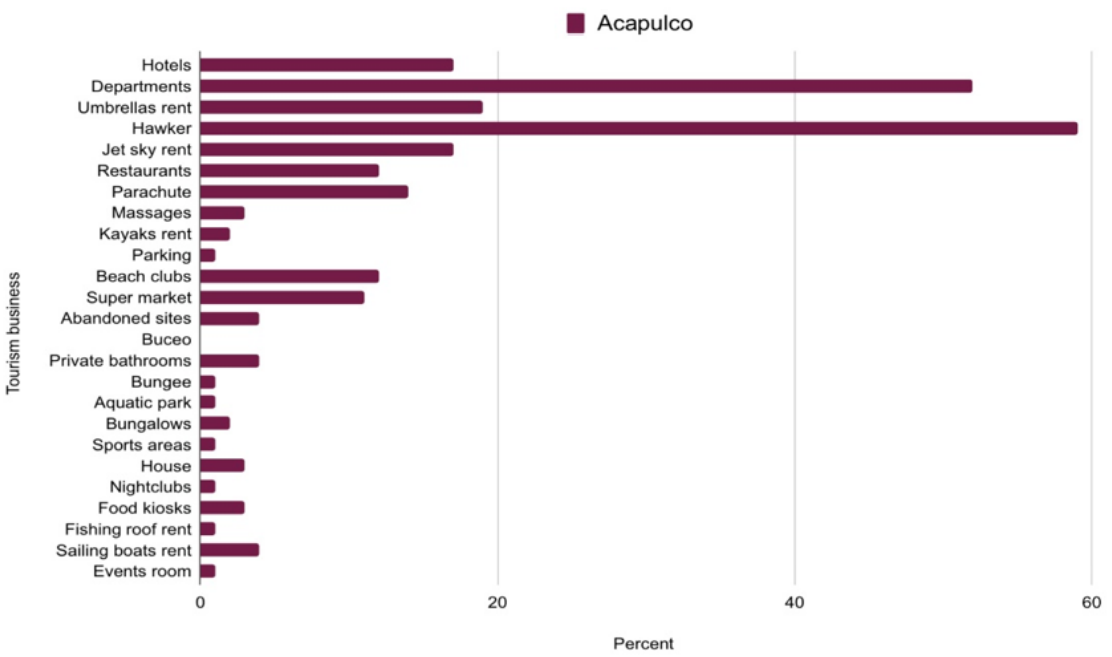

Figure 4: Results in percentages of the inventory of tourism businesses in Acapulco's beaches in 2020.

Source: Own elaboration.

Both destinations registered as main tourism businesses: street vendors, apartments, umbrella rentals, hotels and restaurants, and jet ski rentals.

\section{Comprehensive analysis of tourism businesses} on the beaches. The following comparison between the two destinations is presented within the data collected from the tourism business inventory. The grouping of the businesses in the tables was done according to the researcher's criteria to join similar categories the commercial businesses found during the research.

Table 1. Comparative of tourism businesses on the beaches 2020.

\begin{tabular}{ccc}
\hline Tourism businesses & Mazatlán & Acapulco \\
\hline Hotels & 24 & 17 \\
Departments & 14 & 52 \\
Umbrellas rent & 10 & 19 \\
Hawker & 30 & 59 \\
Jet ski rent & 4 & 17 \\
Restaurants & 11 & 12 \\
\hline
\end{tabular}

Source: Own elaboration.

Table 1 shows that Mazatlán has more hotels than Acapulco; however, this changes when it comes to the buildings marked as apartments; also, they almost show the same amount of establishments regarding the restaurants. Where there is a plurality is in hawkers' existence in the case of Acapulco -which is almost a double- and the rental of umbrellas, tables, and chairs parallel to Jet ski rental's mobile water services. It can be reflected on the type of tourist that both destinations receive, which is close; Acapulco has been characterized by receiving more tourists from Mexico City and visitors to Mazatlán from the north-like states Durango or Jalisco.

Table 2. Comparative of tourism businesses on the beaches 2020 .

\begin{tabular}{ccc}
\hline Tourism business & Mazatlán & Acapulco \\
\hline Parachute rentals & 2 & 14 \\
Massages & 1 & 3 \\
Kayaks rent & 5 & 2 \\
Parking & 5 & 1 \\
Beach clubs & 2 & 12 \\
Supermarket & 1 & 11 \\
Abandoned sites & 2 & 4 \\
Scuba diving & 1 & 0 \\
\hline
\end{tabular}

Source: Own elaboration.

Parachute rentals have a notorious presence in Acapulco and beach clubs and supermarkets or convenience stores, but not boards, kayaks, and raft rentals, which are more common in Mazatlán. There were five for Mazatlán and Acapulco, only one in the spaces marked as parking lots. Regarding the abandoned spaces in the area of beaches (which, although not operating, are essential to note for the investigation), some of them were at some point businesses that, for some reason, ceased to be and closed; in Acapulco appeared four and in Mazatlán two. Scuba diving tours were only present in Mazatlán.

In this case, it is possible to reflect that the profile of the visitor to Acapulco prefers to buy items in supermarkets instead of consuming in restaurants, making the distribution of the economic income 
during their stay different from that of Mazatlán, where visitors make use of the beaches with their vehicles by the same topography of the beaches.

Table 3. Comparative of tourism businesses on the beaches 2020 .

\begin{tabular}{ccc}
\hline Touristic business & Mazatlán & Acapulco \\
\hline Private bathrooms & - & 4 \\
Bungee & - & 1 \\
Aquatic park & - & 1 \\
\hline Source: Own elaboration &
\end{tabular}

The commercial turns found only on Acapulco's beaches were private baths, bungee jumping, and water parks. An interesting reflection is that in the Port of Acapulco, the City Council has concessioned sanitary services to third parties who install and maintain bathrooms where they charge visitors, which in Mazatlán oversee the City Council. We can distinguish in this case that the local administration and adjudication are different and, in the same way, the beaches' urban image in question.

Table 4. Comparative of tourism businesses on the beaches 2020 .

\begin{tabular}{ccc}
\hline Touristic business & Mazatlán & Acapulco \\
\hline Bungalows & 2 & - \\
Sports areas & 1 & - \\
House & 3 & - \\
Nightclubs & 1 & - \\
Food kiosks & 3 & - \\
Fishing roof rent & 1 & - \\
Sailing boats rent & 4 & - \\
Events room & 1 & - \\
\hline
\end{tabular}

Source: Own elaboration.

On the other hand, the touristic businesses exclusively in Mazatlán, not found in Acapulco's beaches, were houses, bungalows, discotheques, events room, rent of fishing rods, rent of sailboats, sports courts, and food kiosks. It is interesting to reflect that Mazatlán has more activities typical of the destination that Acapulco does not have, the bungalows (lodging alternative) Food kiosks, including the nightclub, is an unequivocal example of the prominent influence of tourism from the United States.

Table 5. Comparative of tourism businesses on the beaches 2020 .

\begin{tabular}{ccc}
\hline Touristic business & Mazatlán & Acapulco \\
\hline Total places & 128 & 229 \\
\hline Source: Own elaboration. & &
\end{tabular}

Finally, for the inventory, 128 tourism businesses were counted in Mazatlán and 229 in Acapulco. It should be noted that the route for each of the cases was almost $5 \mathrm{~km}$ and just over $6 \mathrm{~km}$, respectively.

\section{DISCUSSION AND CONCLUSION}

The beach itself is the purpose of the touristic activity, becoming an element of satisfaction for tourists, constituting a decisive factor of traveling by the elements found in it and its periphery. As reported by the World Tourism Organization (UNWTO), the growing number of tourists worldwide increases touristic businesses that must satisfy the expectations of those who visit them. Therefore, this commercial activity must be diversified, innovative, and pertinent in its different tourist activities such as lodging and food, complementing them with shopping, fun, and relaxation, making the destination more attractive to national and international tourists.

The knowledge and analysis of the touristic businesses on the beaches and the relationship with the theory of the touristic destinations forces' life cycle forces to recommend strategies of growth concerning the present and future consumers to whom they will be directed. Marketing channels must be rethought and the promotion of products or services, considering the origin of those who operate these commercial activities.

The tourism businesses on the beaches of the touristic destinations of Mazatlán and Acapulco represent an economic bonanza, the marketing and administration, through various actors in these businesses whether small, medium or large, formal or informal, family or corporate, seasonal or fixed, that shape the tourism industry that must address a sustainable development with proper and timely decision making.

From a global perspective, according to the principal objective to inventory and compare, according to Richard Butler's theory of the life cycle of the tourist destinations, Mazatlán and Acapulco are destinations that have similar tourism businesses. However, each one offers specific products and services that make the tourist decide between one and another. The commercial activity finds its reason for being in the demand of the visitors who arrive at its beaches and answers its requirements and expectations; due to this; it is necessary to take care of the touristic indicators of the profile of the client to establish the right strategies and to offer the products and services that correspond. 
In the case of Acapulco was analyzed and compared with Mazatlán, it is perceived that the link between the touristic area and the city no longer exists, commercial activity is almost unique, and the beaches are used by tourists and by the residents themselves almost without making a distinction. In the case of Mazatlán, there is still a separation that makes a hotel zone and a city where people who work in the Zona Dorada live side by side.

Regarding the future evolution of the studied destinations, several factors should be analyzed, including urban planning, territorial situations, physical situations, and development and growth regulations aligned with environmental ones, strengthening or facilitating a destination's evolution. These factors will be the subject of further research to evaluate other traditional destinations in the future and learn about their commercial activities.

It is considered pertinent to continue analyzing tourist destinations at different stages to visualize trends or projections in the economic sphere and thereby establish commercial strategies explicitly aimed at the market segment they will serve. Knowing the present can give the advantage to prepare for the future and be on the lookout for what will happen, but the comparison between destinations can prevent and anticipate actions to continue being competitive.

In conclusion, Acapulco has more than 90 years of experience in a phase of decline, with a typical infrastructure of its glamorous era and classic tourism businesses that have migrated to a prime destination, fitting out of second homes and apartments with hotel services. Mazatlán, which is nearly a hundred years old in consolidation, keeps the classic hotel industry, led by hotels and restaurants, which do not reject the possibility of migrating -like Acapulco- in a not-too-distant period, to apartment blocks. Both destinations show different competitive advantages and different areas of opportunity, which, if they are not compared and researched from the general will not be able to succeed in particular for future decisions covering the needs of those who make possible the success of these tourism businesses on the beaches, the tourists.

\section{REFERENCES}

Ayuntamiento de Mazatlán (2020). H. Ayuntamiento de Mazatlán. http://sinaloaennumeros.com/tur/

Bejarano, R. (1997). Vegetación y paisaje, Madrid, España: Universidad de Sevilla.

Bryman, A. (2005). Research methods and organization Studies, London, United Kingdom Kindom: Unwin Hyman.

Butler, R. (1980): "The concept of tourist area cycles of evolution: implications for management of resources." Canadian Geographer.

Clark, J. (1996). Coastal Zone Management Handbook. USA: CRC Press.

Creswell, J. (2012). Inquiry and research design choosing among five traditions. USA: SAGE Publications. International Educational and Professional Publisher.

Christaller, W. (1964). Some considerations of tourism location in Europe: The Peripheral Regions Underdeveloped Countries- Recreation areas. Papers in Regional Science, 12 (1). 95- 105

Díaz, M. (2003). Negocios Internacionales. España: Ediciones Pirámide.

De la Torre, O. (2003). El turismo fenómeno social. México: Fondo de Cultura Económica.

Dean, J. (1950). Pricing policies for new products. Harvard business review, 28 (6), 45-54.

Díaz, M. (2014). Negocios Internacionales. España: Ediciones pirámide. 
Gilbert, E. (1939). The Growth of the Island and Seaside Health Resort in England. Scottish Geographical Magazine, 55, 16-35.

Google.(s.f.). Google Maps. https://www.google.com.mx/maps/place/ Mazat|\%C3\%A1n,+Sin./@23.238983,-106.4387639,13z/data=!4m5!3m4!1s0x869f5341681837c 1:0x62a4c4aaf13c72b2!8m2!3d23.2494148!4d-106.4111425

Google. (s.f.). Google Maps. https://www.google.com/maps/@16.846179,-99.8806089,14z

Gundermann, H. (2010). El método de los estudios de caso. México: Porrúa.

INEGI. (2020). Instituto Nacional de Estadística y Geografía. http://www.inegi.org.mx/0

Instituto Turístico de Valencia. (1995). Bases para la ordenación de los espacios turísticos de la comunidad Valenciana. Ed. Institut Turistic Valencia, Valencia.

Marlowe, H. (1999). Assessing the economic benefits of America's coastal regions. Industry- Driven Changes and Policy Respond, USA: SAGE

Miossec, J. (1977). Un modelé de l'espace Touristique. L'espace Géographique, 6 (1) 41-48

Noronha, R. (1976). Review of the sociological literature on Tourism. New York: World Bank.

Rondón, J. (2010). Análisis de los diferentes componentes del ecosistema de playa en Riohacha, Colombia. Recuperado 1 agosto 2014 de: http://www.academia.edu/4985767/INFORME_PLAYA

SECTUR. (2019). Portal del Sistema Nacional de Información Estadística y Geográfica de Turismo. (SECTUR, Ed.): http://www.datatur.sectur.gob.mx/SitePages/ActividadHotelera.aspx

SECTUR (2020) Portal del Sistema Nacional de Información Estadística y Geográfica de Turismo. (SECTUR, Ed.) https://www.gob.mx/sectur/prensa/el-ingreso-de-divisas-turisticas-alcanzo-los-15-mil-666millones-de-dolares-en-el-periodo-enero-agosto

Sonda, R., Escalona, C., \& Morales, R. (2014). La Playa como uso de Negocios Turísticos en Cancún. México: Universidad del Caribe.

Silverman, D. (2011). Interpreting qualitative data. Londres: Sage Publications.

Szilasi, W. (2010). Introducción a la fenomenología de Hussherl. España: Amorrortu Editores.

Vistimexico. (2020). Consejo de promoción turística de México. Acapulco. https://www.visitmexico.com/es/ destinos-principales/guerrero/acapulco

Verbiclara. (2019). Origen de la palabra negocio. https://verbiclara.wordpress.com/2016/03/05/origen-dela-palabra-negocio/

Yepes, V. (1999). Las playas en la gestión sostenible del litoral. España Universidad de Murcia. 